Roumen Daskalov (Sofia)

iD https://orcid.org/0000-0001-7136-0001

\title{
Historical Master Narratives and the Master Narrative of The Bulgarian Middle Ages*
}

\section{Historical master narratives}

Cholars and journalists began talking about grand narratives (or master nar$\mathcal{H}$ ratives or metanarratives) after Jean-François Lyotard's well-known work The Postmodern Condition. A Report on Knowledge ${ }^{1}$. Lyotard spoke about grand narratives (grands récits) in connection with the legitimation (or justification) of scientific knowledge. More specifically, he considered the emancipatory narrative of the French Revolution about liberating mankind from the shackles of priests and tyrants. He also considered the speculative narrative of German idealism (Fichte and Hegel) about the dialectics of the Spirit (or the realization of the Idea) as a meta-principle, as well as the narrative on relations between science, nation, and state (made more explicit by Humboldt). According to Lyotard, these narratives have lost their persuasiveness and credibility in the postmodern conditions. After Lyotard, the idea of grand narratives became popularized and entered various fields, one of which is historical scholarship.

Allan Megill differentiates several types of narratives in historical scholarship: narrative proper; master narrative, which claims to offer an authoritative account of a given segment of history; grand narrative, which claims authoritatively to explain history in general (for example, the development of history towards a "civic union" of the human race, as with Kant, or as a progressive realization of freedom, as with Hegel); and metanarrative, which serves as a justification of the grand narratives, most often belief in God or in an immanent rationality of the world ${ }^{2}$.

\footnotetext{
* I would like to express my warmest gratitude to Gerda Henkel Foundation for supporting my work on this project about national historiographies and historiography wars.

${ }^{1}$ J.-F. Lyotard, The Postmodern Condition. A Report on Knowledge, Manchester 1984 (French edition, 1979), p. XXIV-XXV, 31-34, 37-38, 51, 60, 65.

${ }^{2}$ A. Megill, "Grand Narrative" and the Discipline of History, [in:] A New Philosophy of History, ed. F. Ankersmit, H. Kellner, Chicago 1995, p. 152-153.
} 
Yet the use of the terms is not codified, and the various authors use them interchangeably or fuse two categories. To quote one definition, the representations of the past attain the status of a metanarrative "when their validity is not contested or at least they are socially dominant and form a magnetic field that is capable of integrating and orienting in a unified way the various particles of the historical representations"3. Or a shorter one: "metanarrative, that is, a narrative that arranges a number of other histories"4.

Konrad Jarausch and Martin Sabrow describe the various components and functions of the master narratives. These include a substantive aspect consisting of events, personalities, and structural interrelations. There is a theoreticalmethodological dimension, in other words, claims of veridical argumentation and positing of criteria of rationality. There is a semantic component consisting of the use of a specific vocabulary and the following of narratological rules. There is a discursive deep structure, that is, a meaningful arrangement of the past, creation of coherence, and organization of the historical discourse. And there is the relation to social practices of generating a tradition (and identity) and a politics of history. The master narratives attain social hegemony through institutionalization, dissemination through the media, and political scenarios. The same authors point to the critical potential of the very notion of master narratives, which respects the effort to achieve directedness and synthesis but at the same time points to the constructed character of every writing of history and indicates that the past is not "in itself" but "for us" and depends on present interests. The concept thus contains a critique of any attempt to dictate the viewing of the past and of the arrogance of asserting "how it really was". In other words, it is directed against historical monism in favor of the historical pluralism characteristic of the twenty-first century (and of postmodernism) 5 .

The master narratives satisfy the society's identificatory and other important needs and help in achieving social integration, as they react to changes in the society with a change in the dominant interpretations. They also offer orientation in the future. With the rise of the nation-states and nationalism in the nineteenth century, the master narratives became a product and a factor of this new type of social integration. The history of one's own nation became the major interpretative framework for ordering and fusion of historical knowledge in a meaningful master narrative - the nation is legitimized by constructing a continuity from

\footnotetext{
${ }^{3}$ M. Middell, M. Gibas, F. Hadler, Sinnstiftung durch historisches Erzählen. Überlegungen zu Funktionsmechanismen von Representationen des Vergangenen, [in:] Comparativ, Zugänge zu historischen Meistererzählungen, ed. IIDEM, Leipzig 2000, p. 24. Another definition appears in K. JARAusCH, M. Sabrow, "Meistererzählungen": Zur Karriere eines Begriffs, [in:] Die historische Meistererzählung. Deutungslinien der deutschen Nationalgeschichte nach 1945, ed. IIDEM, Göttingen 2002, p. 16.

${ }^{4}$ L. HunT, Geschichte jenseits der Gesellschaftstheorie, [in:] Geschichte schreiben in der Postmoderne, ed. C. Conrad, M. Kessel, Stuttgart 1994, p. 113.

${ }^{5}$ K. Jarausch, M. Sabrow, "Meistererzählungen"..., p. 11-12, 17-18.
} 
its mythical origins up to the present. The master narratives feature a deep structure that relates to fundaments of the cultural community, and, along with that, the ordering of time according to periodizations that reflect respective judgments of the course of history, such as myths of origins, stories of rises and peaks, and phases of decay or stagnation - all marked by events. They are organized around important actors and events, refer to a certain space, and introduce differentiations, namely, the divide between "us" and the "others" ("them"). The master narratives were problematized in many European states after 1945 through alternative attempts, e.g., the transnational study of the common foundations of the "West", and the universal-historical dimension of Marxism, but these alternative interpretations often remain attached to the national-historical model ${ }^{6}$.

The master narratives I am concerned with here are exactly of the national type, national master narratives, because they are deployed in the national framework and have the nation (or people) and its state as their major (collective) agent. The Marxist counter-narrative, which attempted to replace the nation with classes but remained (in the Bulgarian and other cases) within the national framework, will also be analyzed.

The close relation between historiography and justification of the nation, as well as the "nationalization" of history in the sense of presenting the nations as the major historical actors and privileging the national point of view, are universal or at least European phenomena. They appeared with the assertion of the national principle and the creation of modern nations and nation-states in the second half of the eighteenth century and throughout the nineteenth century, and they coincided with the scientification and the professionalization of the historical discipline $^{7}$. The national principle of organization of the historical narrative made its appearance with Romanticism in the early nineteenth century, with its ideas of the unique character of the nation, its legitimation of the nation by stressing continuity in history, its affirmation of the superiority of one's nation over other nations, and its strongly gendered approaches to describing nationhood. Then the national principle of organization became the hallmark of positivist historiography of the second half of the nineteenth century, with its orientation, if not toward "laws" in the human affairs, then at least toward empiricism and a critique of the sources. The same principle passes through some varieties of Marxism.

"Scientific" history was accorded a major role in the formation of nations and the building of national identities and national "historical consciousness", hence of a national loyalty and attachment, and thus the legitimation of the nation-states.

\footnotetext{
${ }^{6}$ M. Middell, M. Gibas, F. Hadler, Sinnstiftung..., p. 25-28, 30.

${ }^{7}$ On the professionalization and institutionalization of historical scholarship, which first took place in Germany, see P. LAmbert, The Professionalization and Institutionalization of History, [in:] Writing History. Theory and Practice, ed. S. Berger, H. Feldner, K. PAssmore, London 2003, p. 42-60. ${ }^{8}$ S. BERger, Introduction: Towards a Global History of National Historiographies, [in:] Writing the Nation. A Global Perspective, ed. IDEM, Basingstoke 2007, p. 4, 9-13.
} 
Accordingly, the historians assumed the role of nation-builders and "spokespeople" for the nation, upholders of the national honor and glory, and national pedagogues in general. In more extreme cases, they became apologists of the nation and developed a cult of the state?

The national narratives typically operate with models of rises and falls, golden ages, lost lands, national renaissances, national heroes, ideas of national missions, ideal borders and territories, and the continuous existence of states, the longer the better. In the absence of state continuity, ethnic continuity and the heroic struggle of the people against a foreign domination take center stage ${ }^{10}$. In a general sense, the national narratives can be optimistic, such as the American and the French "histories of success". In the American case this involves concealing historical crimes such as the extermination of the Native Americans, the enslaving of other races, and imperialist exploitation. Other national master narratives have a pessimistic overtone: the Polish and the Serbian histories are histories of suffering with martyrological self-pity and victimization that risk inflaming a desire for revenge. In some cases, as in the Balkans, the national narrative presents a secularized history of salvation - after a demonstration of a glorious past, the spread of the national-liberation movements brings salvation from Ottoman rule and the establishment of independent nation-states ${ }^{11}$.

Some national and nationalist historians insist that historical scholarship should be scientific, "objective", and "value-free" (in the Weberian sense), i.e., without biases and value judgments. Others advocate taking sides and favoring a (national) "party" stand (Parteilichkeit, not very different from the communist tenet on the issue of classes). It is exactly in criticizing the national paradigm in historical scholarship since the early nineteenth century, which reached the extreme of national apologetics, that the notions of "objectivity" and "freedom of values", as well as the strict separation between scientificity and politics (and ideology), have been challenged. They have been accused of being a "new metaphysics" actually concealing national biases or, at best, a rhetorical weapon in institutional power competition between historians for careers and promotions and a way to exclude "amateurs"12.

\footnotetext{
${ }^{9}$ S. Berger, M. Donovan, K. Passmore, Apologias for the Nation-State in Western Europe since 1800, [in:] Writing National Histories. Western Europe since 1800, ed. IIDEM, London-New York 1999, p. 3-14. On the German national tradition of historiography, see S. BERGER, The Search for Normality. National Identity and Historical Consciousness in Germany since 1800, Providence-Oxford 1997. Berger extends his observations to other European national historiographies and (in a work resulting from collective research) to the way of writing national history in Europe. See S. BERGER, The Power of National Pasts: Writing National History in Nineteenth-and Twentieth-Century Europe, [in:] Writing the Nation..., p. 30-62. See also Historians as Nation-Builders. Central and South-East Europe, ed. D. Deletant, H. HanaK, Basingstoke-London 1988. This is a more traditional treatment of some national Central European and Balkan historians.

${ }^{10}$ S. BERGER, Introduction..., p. 5, 9, 23-24.

${ }^{11}$ K. Jarausch, M. Sabrow, "Meistererzählungen"..., p. 29-30.

${ }^{12}$ S. Berger, M. Donovan, K. Passmore, Apologias..., p. 4-5.
} 
Let us return to the national master narratives with some examples. In Germany the national narrative was initially elaborated by the historians of the "Prussian school” Johann Gustav von Droysen, Henrich Siebel, Henrich von Treitschke, and others. It pared down the variety and heterogeneity of individual confessional and territorial (regional) histories and oriented the narrative mainly toward the rise of Brandenburg-Prussia as the nucleus of the future unified state. After the national goals were realized, the national history turned into legitimation and a veritable cult of the statehood and power of the German Empire ${ }^{13}$. After 1945 (but not immediately after), with the rise of social history starting at the end of the 1960s, a new "grand narrative" of the Federal Republic developed. This was the thesis that there was a particular negative German path of development (Sonderweg) that led to Nazism within the metanarrative of modernization ${ }^{14}$.

Joep Leerssen underlines the significance of the beginning, middle, and end of the stories. Yet in his opinion, the beginning and the end of historical narratives are somewhat anomalous; although the histories start and end somewhere, these are not proper narrative beginnings and ends. The beginning is in many cases a review of the setting - either the geographical setting or the circumstances in which the historical events will take place - while the end is often something like a moral balance of the significance of the events described. Leerssen considers the beginning of some national histories, in which the coincidence between ethnicity and territory, that is, an early settlement of a certain people on a certain territory, represents the ideal case. Such a fortuitous continuity between ethnicity and place of settlement is present in the case of Germany. When such continuity is lacking, as in the case of Belgium, the unity of social life (commerce and traffic) is stressed instead. Ireland has to be satisfied with a legendary beginning, followed by an invasion by the Celtic Galli as a real historical beginning (and an ideal of future independence) ${ }^{15}$.

The Middle Ages in particular also generate master narratives and become "nationalized" in a variety of ways, even when stating that nations did not exist at the time. As Patrick Geary has pointed out, medieval history is always in a subordinate position and serves as a negative otherness and the opposite image of the grand narratives of the modern age. If the modern age is known for "progress", "reason" or "rationality", "science", "the liberation of the individual", and "liberal democracy" (initiated during the Renaissance and achieved during the Enlightenment), the Middle Ages stand for the opposite notions and values: the traditional irrational world, lack of a developed personality and of interest for the material world.

\footnotetext{
${ }^{13}$ K. Jarausch, M. Sabrow, "Meistererzählungen"..., p. 25-26. In more detail, see S. Berger, The Search for Normality..., p. 21-55.

${ }^{14}$ T. Welskopp, Identität ex negativo, [in:] Die historische Meistererzählung..., p. 109-139.

${ }^{15}$ J. Leerssen, Setting the Scene for National History, [in:] Nationalizing the Past. Historians as Nation Builders in Modern Europe, ed. S. Berger, C. Lorenz, Basingstoke-New York 2010, p. 71-85.
} 
With such a negative image of the Middle Ages, the medievalist has several options for constructing a meta-narrative about them. The first is to reject the autonomy of the Middle Ages by denying them their own era in periodizations (by prolonging antiquity until very late and starting immediately with "Old Europe"). The second is to assert the otherness of the era between 500 and 1500 with a positive or negative attitude toward medieval religion, culture, and society, and sometimes even with fascination with morbid things (death, blood, violence, pain, pus). The third is to attempt to show that the Middle Ages, like modern times, are part of the narrative of rationalization and emancipation (the beginnings of a modern economy and capitalism, navigation, various cultural renaissances, and so on). The fourth is to problematize the modern age itself as a history of progress and to show the medieval roots of modern intolerance, repression, and violence.

Geary recognizes the usefulness of the narrative paradigm but rejects the radical epistemological theses of postmodernism (such as closure within language and lack of referentiality to reality, or that the narratives are just formulae of power and desire). He opts for multiple Middle Ages by decentering vis-à-vis Europe and its "provincialization" (as Dipesh Chakrabarty has it) on the example of the postcolonial (subaltern) studies and of Eurasian and global history, as well as the history of women and of minorities with their alternative narratives of the modern age (not just criticism and deconstructionism) ${ }^{16}$.

Some authors view the master narratives of the Middle Ages in a positive light, pointing to their important orienting and directing functions. These include the determination of the basic structure of the historical narrative, the ordering of historical knowledge in coherent frameworks and the ascription of meaning, and the reduction of complex historical interrelations to simple schemes and dichotomies (e.g., unity versus freedom, community based on equality [Genossenschaft] versus community based on domination [Herrschaft]), and thus the rendering of coherence and meaningfulness and the possibility to narrate the historical process in general ${ }^{17}$. One should also mention the important insight that the Enlightenment, the modern age, and postmodernism (as well as the Renaissance and the Reformation) and every present all have their "own" Middle Ages. Conversely, the Middle Ages are a precondition for thinking about the modern age ${ }^{18}$.

\footnotetext{
${ }^{16}$ P. Geary, "Multiple Middle Ages" - konkurrierende Meistererzählungen und der Wettstreit um die Deutung der Vergangenheit, [in:] Meistererzählungen vom Mittelalter, ed. F. Rехвотн, Munich 2007, p. $107-120$.

${ }^{17}$ F. Rexroth, Meistererzählungen und die Praxis der Geschichtsschreibung. Eine Skizze zur Einführung, [in:] Meistererzählungen..., p. 4-6, 8. Also W. PoHL, Ursprungserzählungen und Gegenbilder. Das archaische Frühmittelalter, [in:] Meistererzählungen..., p. 29-35. See also P. RaEdTs, The Once and Future Reich: German Medieval History between Retrospection and Resentment, [in:] Gebrauch und Missbrauch des Mittelalters, 19.-21. Jahrhundert, ed. J. BAK, J. Jarnut, P. Monnet, B. SchneidMÜLLER, Munich 2009, p. 193-204.

${ }^{18}$ O. OexLe, "Das Mittelalter": Bilder gedeuteter Geschichte, [in:] Gebrauch und Missbrauch..., p. 27-28.
} 
Special attention is paid to the narratives of the Early Middle Ages, because the origins of the modern nations are sought there, and it is from there that the comprehensive national master narratives take their start. Walter Pohl gives examples of master narratives about the ancient beginnings of the West. These include the monasteries as islands of written culture and gradual spread of literacy; the process of social disciplining and of taming and civilizing of behavior and mores as a precondition of the industrial society (Norbert Elias); and the evolution of statehood. Yet according to Pohl, all master narratives about the Early Middle Ages go beyond them and transcend them, treating them as a time of decay, transition, or origins, while the real interest is directed to another era, so he argues that the Early Middle Ages should be understood in and of themselves in their multiplicity and contradictions. As for the master narratives, he thinks that they are not necessarily mistaken and can be a productive challenge ${ }^{19}$.

Pohl considers in another work the modern uses of early medieval ethnic descent on the examples of Germany, France, England, Spain, Greece, Italy, and (more briefly) Central and Southeastern Europe ${ }^{20}$. Here I will only touch upon the treatment of the German, French, and British examples, which are of some relevance for the Bulgarian case. As Pohl points out, early medieval history is always entangled with issues of national identity, and national histories everywhere have contributed to the creation of national myths of origins. Although the national ideologies reached their peak in the first half of the twentieth century (the most aggressive until 1945 was German nationalism, with the racist belief in biological Aryan German superiority), in some countries the controversies over medieval descent still have nationalist overtones today.

According to the national myth of origins, present-day Germans are considered heirs to the Germanic rulers' conquests of much of Europe by Germanic tribes during the Great Migration of Peoples (Völkerwanderung). More problematic are the Early Middle Ages, because some German kingdoms lasted only a short time and because Clovis and Charlemagne (or Charles the Great) ruled the successful Frankish Kingdom, which, however, has a more direct link with the present-day French state (and the Franks gave their name to the French). For that reason, German nationalist historians turned mostly to the Otons, under whom the Holy Roman Empire turned into a kingdom of the Eastern Franks (together

\footnotetext{
${ }^{19}$ W. PoHL, Urspungserzählungen..., p. 23-41.

${ }^{20}$ IDEM, Modern Uses of Early Medieval Ethnic Origins, [in:] Gebrauch und Missbrauch ..., p. 55-70. As Pohl points out, most conflicts during the early Middle Ages were not national, but this is the period when ethnic states (kingdoms named after peoples) started to expand in Europe. On the French case, for more detail, see B. Efrros, The Germanic Invasions and the Academic Politics of National Identity in Late Nineteenth-Century France, [in:] Gebrauch und Missbrauch..., p. 81-94; A. BURGUiÈrE, L'historiographie des origines de la France: Genèse d'un imaginaire national, A.H 58.1, 2003, p. 41-62. On the mythologizing and politicizing of the origins, see also P. GeAry, The Myth of Nations. The Medieval Origins of Europe, Princeton-Oxford 2002, p. 15-40.
} 
with other Germanic tribes, such as Saxons, Bavarians, and Alamani), who would eventually evolve into Germans. In fact, the German state evolved in a protracted and punctuated process from the Frankish Kingdom (still called the Holy Roman Empire), where most of the inhabitants were more attached to regional identities. Only in the course of the nineteenth century did the idea of a common German identity succeed in a protracted competition with other particularistic identities (connected with the names and areas of other Germanic tribes).

The history of the French is also connected with the early medieval Franks; the paradox is that a Germanic-speaking people gave its name to a Romanicspeaking nation. Traditionally, the French aristocracy claimed descent from the Franks, and at the beginning of the eighteenth century, the theory of the two races was elaborated (by the aristocrat Boulainvilliers), namely, the Franks, who were freedom-loving and capable of governing, and the subjugated Galli. However, this was countered with the argument that the French monarchy was a legitimate heir to the Roman Empire, which legally transferred the government of Gaul to the Franks, whom the Roman emperor called upon for the defense of the borders. Hence they came by invitation as workers and soldiers and not as conquerors, and they were later assimilated by the Gallo-Roman population without leaving significant traces. The influence of the Roman tradition was thus underscored (by Foustel de Coulange) rather than ethnic descent. One traditionally contested point has been Charlemagne: was he French or German? The French Revolution accepted the (ethnic and social) division into Franks and Galli but reversed the assessments. It declared that the real French (the third estate, or tiers état) were heirs of the Galli, who suffered under foreign domination and who formed the nation. The debate about the origins of the French became strongly aggravated after Prussia defeated France in 1871, but it later subsided. Since 1945, French history has been defined territorially (the "hexagon") and institutionally, while Charlemagne has been symbolically appropriated as the "father" of united Europe.

No less complicated is the issue of British origins and identity. The Germanic tribes the Angles and Saxons, the future Englishmen, came to Britain in the fifth and sixth centuries. Here they encountered and attacked or repulsed not only the Brits (i.e., Romanized Celts) but also other Celtic tribes who were among the forerunners of the present-day Welsh, Scots, and Irish. In the eleventh century the Normans (French) invaded the British Isles and centralized the political system. They were subsequently Anglicized (also in a linguistic sense).

Some medieval myths, once they are deeply imprinted in the consciousness, can be instrumentalized and manipulated for political purposes. One such case can be seen in Serbia with the myth of the Battle of Kosovo against the Turks (1389), which served to foster a dangerous and bloody nationalism ${ }^{21}$.

${ }^{21}$ See, for example, M. ŠuicA, The Image of the Battle of Kosovo (1389) Today: A Historic Event, a Moral Pattern, or the Tool of Political Manipulation, [in:] The Uses of the Middle Ages in Modern European 
The question can be asked: what is the attitude toward the master narratives today, and toward national ones in particular? The author of the notion, Lyotard, believes that the grand narratives, which exercise a totalizing, and in some cases even totalitarian influence and control, have lost credibility. As an alternative, he offers what he calls "small narratives" (petit récits) or micro-narratives - local, contingent, and popular, expressing a variety of circumstances and unresolved conflict, and for that reason not subject to totalization. According to him, such narratives derive from customary knowledge, and they have a pragmatic and performative function and local authority and heterodox socio-political power - they produce social and political resistance and subvert the institutionalized narratives with their power props ${ }^{22}$.

The master national narratives seem to have lost credibility in the great national historiographies, or at least they are meeting resistance, and alternatives are sought. Such alternatives include (in an early timeframe) the history of the working classes, and later on women's history, though both are often narrated in national frameworks, and might, for that reason, be called (as Stefan Berger calls them) national counter-narratives ${ }^{23}$. Berger notes a certain loosening of the homogeneous national paradigms in general. This happens especially through the categories of "remembrance" and "memory", through the "history of everyday life" and "microhistory", as well as in postmodern strategies of narrating history, which insist upon the multiplicity of subjective "memories" and upon taking various perspectives and experiences into account. These also reflect why and by whom particular pasts are constructed, and, along with that, certain representations of the future, while others are barred from the public discourse. Berger takes a stand against homogeneous identitary national discourses in the writing of history in favor of a historiography that would validate different identities in their conflictual relations and would insist upon the simultaneous existence of multiple constructs of identity. Even more radically, he states that the representation of the past should not recreate mythical roots of the national identity but, on the contrary, should dissolve the ideas of imagined identities and identify the myths underneath them. (He cites Foucault's dictum that it is not the goal of history to offer "substitute identities" to people who do not know who they are $)^{24}$.

\footnotetext{
States, ed. R.J.W. Evans, G.P. Marchal, Basingstoke 2011, p. 152-174; D. DJokić, Whose Myth? Which Nation? The Serbian Kosovo Myth Revisited, [in:] Gebrauch und Missbrauch..., p. 215-233.

${ }^{22}$ J.-F. Lyotard, The Postmodern Condition..., p. 60, 66; M. Kreiswirth, Tell Me a Story: The Narrativist Turn in the Human Sciences, [in:] Constructive Criticism. The Human Sciences in the Age of Theory, Toronto-Buffalo-London 1995, p. 71-72.

${ }^{23}$ S. BERGER, Introduction..., p. 19.

${ }^{24}$ IDEM, Geschichten von der Nation. Einigen vergleichende Thesen zur deutschen, englischen, französischen und italienischen Nationalgeschichtsschreibung seit 1800, [in:] Die Nation schreiben. Geschichtswissenschaft im internationalen Vergleich, ed. C. ConRAD, S. ConRaD, Göttingen 2002, p. 77; IDEM, The Search for Normality..., p. 6-7.
} 
Konrad Jarausch also makes it clear that nation, class, and the modern age are losing their meta-status and that the master narratives have been eroded, including the narrative of the German Sonderweg to modernization, not to speak of the Marxist alternative in the former East Germany. Especially in Germany, this erosion took place under the impact of the political upheavals in 1945, 1968, and 1989 , as well as under the impact of the postmodern critique (which leads to methodological relativization) and the competition of individual remembrances and medial images. He lists the alternative metanarratives and grand interpretations on offer, such as an updated theory of totalitarianism to explain the two German dictatorships (the Nazi regime and the GDR's communist regime), the Holocaust, the counter-narratives of minorities, territorial alternatives (subnational, regional, or the geographical perspective of the whole of Europe, as well as a globalized "history of the world"). Other alternative grand narratives, with less relevance for Germany, are the postcolonial discourses in the United States, Britain, and France and the "subaltern stories" of black or colonial peoples, counterposed to master narratives taken literally.

Jarausch, however, remains skeptical that these or other new grand or master narratives can take root, given the competition of historical images transmitted through the media and their inability to inspire the intellectuals. He even notes the rehabilitation of a democratized national history as the ironic consequence of offering all the aforementioned alternatives. He argues for a pluralization of the historical narratives within a tolerant democracy (e.g., many histories of the Germans and the German past - local, confessional, social, and ethnic) and a multivocality or "polyphony" of cross-cutting historical narratives - without, however, fusing them into a new, if decentered, metanarrative. In this way the complexity of the past will be seen and a multi-perspectival understanding of it will be achieved, in which historical research will also enter into a dialogue with popular remembrances and memories about $\mathrm{it}^{25}$.

On the other hand, influential historians like Jörn Rüsen think that a cultural identity simply cannot exist without grand or master narratives, and that even if the critique of such narratives is justified, we need new such grand narratives in order to define our identity in a new way ${ }^{26}$. Even a thinker of the rank of Michel Foucault, who departed from a critique of one grand narrative, of liberalism and progress, ended up creating another grand narrative, of increasing social control and disciplining in the modern "carceral society". The irony, as some have pointed out, is that historians are faced with a public demand for comprehensive narratives,

\footnotetext{
${ }^{25}$ K. Jarausch, Die Krise der nationalen Meistererzählungen, [in:] Die historische Meistererzählung..., p. 140-162.

${ }^{26}$ J. RüsEn, Für eine interkulturelle Kommunikation in der Geschichte, [in:] Die Vielfalt der Kulturen (Erinnerung, Geschichte, Identität 4), ed. J. Rüsen, M. Gottlob, A. Mittag, Frankfurt am Main 1998 , p. 23.
} 
whose status they themselves consider more and more problematic, yet to which they owe their social significance ${ }^{27}$.

Until this point, I introduced the notion of historical master narratives and national master narratives in particular, their general models (or plots) and contribution to national identities and justification of the nation and its state. I then addressed the issue of master narratives of the Middle Ages with their typical themes (such as origins, ethnogenesis, continuity, etc.) and their orientation and identity-building function. I now come to the national narrative and counternarrative of the Bulgarian Middle Ages and I will consider their general mode of operation and some specific themes.

\section{Master narratives of the Bulgarian Middle Ages}

Here I will briefly and schematically present the master narrative of the Bulgarian Middle Ages, which is the subject a detailed book of mine in Bulgarian ${ }^{28}$. This master narrative was constructed starting with what is known as "Romantic" historiography (from Monk Paisij's "Istorija Slavjanobolgarskaja" [Slavonic-Bulgarian History] in 1762 to Vasil Aprilov's writings in the first half of the nineteenth century) but it was elaborated especially with the development of "scientific" (or critical) historiography first by Marin Drinov (1838-1906) and mainly by the most significant Bulgarian historians from the "bourgeois" era: Vasil Zlatarski (1866-1935) ${ }^{29}$, Petăr Mutafčiev (1883-1943) ${ }^{30}$, and (to a point) Petăr Nikov (1884-1938) $)^{31}$. Then it was interrupted by the (crude) Marxist counternarrative of the late 1940s through the beginning of the 1960s. Starting in the midor late 1960s there was a gradual return to the nationalism of the master national narrative, which reached a peak with the celebration of the $1,300^{\text {th }}$ anniversary

\footnotetext{
${ }^{27}$ M. Middell, M. Gibas, F. Hadler, Sinnstiftung..., p. 18-20, 22.

${ }^{28}$ Р. ДАскалов, Големите разкази за Българското средновековие, София 2018.

${ }^{29}$ В. ЗЛАТАРски, История на българската държава през средните векове, vol. I, Първо българско иарство, р. 1, Епоха на хунно-бблгарското надмощие, 679-852, София 1918; IDEм, История на българската държава през средните векове, vol. I, (Пврво българско изарство), p. 2, (Oт славянизацията на държавата до падането на Първото българско иарство, 852-1018), София 1927; IDEм, История на българската държава през средните векове, vol. II, България под византийско владичество, 1018-1187, София 1934; IDEм, История на българската държава през средните векове, vol. III, Второ българско изарство. България при Асеновии, 1187-1280, София 1940.

${ }^{30}$ П. МутАфчиЕв, Изток и Запад в европейското средновековие, София 1999 (first published in 1931); IDEм, История на българския народ, vol. I-II, София 1943; IDEм, Книга за българите, София 1999 (first edition in 1987, written in 1928-1936).

${ }^{31}$ П. Ников, Българо-унгарски отночения от 1257 до 1277 година, СбБАН 11, 1920, p. 1-220; IDEм, Татаро-български отночения през Средните векове с оглед към ияаруването на Смилеца, София 1921; IDEм, Българи и татари в Средните векове, София 1929; IDEм, Съдбата на северозападните български земи през средните векове, БИБ 3.1, 1930, p. 96-153.
} 
of the founding of the Bulgarian state in 1981. The same line continued after 1989 (stripped of the Marxist vulgata), yet some new tendencies appeared.

Master national narratives despite all their variations, have certain thematic nodes. These typically include origins and migrations, the founding of a state and its evolution, rise and decline, foreign dominations, yet with the assertion of continuity (at least of the "people"). Important substantive themes (and plots) in the course of this narrative in the Bulgarian case, apart from those already mentioned, are Christianization, adoption of an alphabet, formation of the nationality (ethnogenesis), and the Byzantine influence (called "Byzantinism"). The communist counter-narrative added to these the themes of feudalism and class struggle. One can also note some dichotomies that structure the material, form the plot or intrigue, and serve to make sense of the events, such as the dichotomy "domination" versus "equal union" (between Bulgars and Slavs), ethnic dualism versus unity or fusion, paganism versus Christianity, original model versus Byzantine influence, and centralism versus (feudal) decentralization.

Origins and ethnogenesis are especially important for collective identity. The Bulgarian case involves two basic and quite different ethnic components, and it is still more interesting because the way relations between them were perceived depended upon the changes in the sociopolitical circumstances and context. It is notable that other ethnic elements are stubbornly excluded from the Bulgarian ethnogenesis (except for the Thracians as a third and minor element) and that the master narrative insists that the process is completed early and the ethnic community or nationality is stabilized precisely to exclude later ethnic additions (or to belittle them as "assimilated") but also to lay claim to Macedonia in this early epoch under Bulgarian rule. In this way, the master national narrative ensures the continuity of the ethnic group or nation and its identity: we are the same now as they (or even "we") were then.

The main protagonist of the master national narrative is the state, represented by its rulers; "the people" are in the background. The rulers are typically divided into "strong" or "weak", "wise" or "short-sighted", "military leaders" or "diplomats", and, in the final analysis, "successful" or "unsuccessful". The master national narrative shows particular interest in statehood in the sense of institutions and state traditions, as well as in the church. The national narrative is particularly insistent in asserting the continuity of state tradition - between the two Bulgarian medieval states; between the eastern part of the first Bulgaria, which fell under Byzantine domination earlier (in 971), and the western part (Macedonia) of King Samuil, which fell later (in 1018); and between the Bulgaria of Khan Asparuh on the Danube (founded in 681) and the preceding Bulgaria of Khan Kubrat to the north of the Caucasus (in the 630s through the 660s). The continuity of the state and Church tradition is added to ethnic continuity as a main thread in the master national narrative and a guarantee of identity. 
The master narrative of the Bulgarian Middle Ages has two peaks or culminations - the periods of greatest military and political might and territorial expansion under Tsar Simeon the Great (reign: 893-927) during the First Bulgarian Kingdom and under Tsar Ioan (in Bulgarian, Ivan) Asen II (reign: 1218-1241) during the Second Bulgarian Kingdom. In fact, there is a third peak, which is situated outside the Middle Ages but is implicitly a comparative point of reference for them as well. This is the map of Bulgaria of the (abortive) San Stefano preliminary peace treaty of March 1878 after the Russo-Turkish War of 1877-1878, which became the Bulgarian national "Great Idea" but could not be realized during the Third Bulgarian Kingdom then established (except temporarily). All three "Great Bulgarias" included Moesia (today's Northern Bulgaria), Thrace, and Macedonia, so that Bulgaria bordered "three seas" (as the nationalist slogan goes). The Middle Ages and Bulgarian history in general are conceived of through this maximalist territorial expanse, which stands as the "Bulgarian lands" or, more strongly, as "original Bulgarian lands", even though the outer parts were under Bulgarian rule for only a short period of time. Moreover, the actual map of the Bulgarian medieval kingdoms usually looked very different, and in some periods it had little in common with this national ideal. It is against this mental map (or map in the minds) of a Greater Bulgaria that the past and every present were measured. For a long time, the "regaining", "liberation", and "unification" of the remaining lands that constituted "all-encompassing" (tselokupna) Bulgaria was the political goal to be pursued. In this way the Middle Ages were also included in the modern Bulgarian national project as its antecedent and analog, so that the periods of the three kingdoms appear to be new beginnings, expansions, and efforts toward the same political goals and, ultimately, unsuccessful repetitions. The territorial continuity (or, put more strongly, identity) is added to ethnic and state continuity to complete the modern national identity.

In Bulgarian medieval history, there were two periods of foreign domination resulting in the disappearance of the state - under the Byzantines and under the Ottomans. There was also a period in which the state became extremely weak and dependent on the Tartars during the Second Kingdom. Apart from that, there were periods of "feudal disintegration", mostly during the Second Kingdom. How does one narrate the periods under foreign rule, without Bulgarian statehood? The Bulgarian people remain as a collective hero. Yet the master national narrative is not interested in their everyday life but mostly in the dramatic moments of suffering and struggle, in which the heroic aspect is emphasized over victimization and its negative consequences (like assimilation). In any case, the narrative of the period under Ottoman rule (emotionally called "slavery") remains a "small narrative" (also in terms of the number of pages) because of the absence of "high" official national culture (state, church, and rulers of the same nationality), which stand at the center of interest of the master national narrative. 
Apart from the state with its rulers (and patriarchs of the Church), the master national narrative also has "the people" as its protagonist. "The people" are not an invention of communist historiography, though there they feature as an active participant (waging "class struggles") rather than only passively suffering from oppression and exploitation. The national/nationalist "bourgeois" historical discourse, however, also paid attention to the "people", although it regarded the people more as a passive "object" and not a "subject" of history, except in special cases of popular movements (such as the Bogomil heresy in the tenth century or the peasant uprising of Ivaylo in 1277-1280). In the Bulgarian case, the fact that the historians branded as "bourgeois" came from commoner or, at best, middleclass milieus accounts for their sympathizing with the common people rather than with the elites.

Along with their empirical (mostly passive) existence, "the people" in the master national narrative also have a purely transcendental and normative function: they serve as a distinctive moral measuring rod to judge the rule of the rulers. Good rulers should not exhaust the people in major wars (hence the negative judgment of Simeon the Great by some historians). Nor should they allow "feudal" arbitrary rule over the people. Furthermore, there is the idea that the state's strength is maintained by the "unity" between the people and the ruler, who must keep the predatory and egotistic feudal lords in check. Conversely, heavy oppression of the people drives it to indifference and despair, which triggers heresies and weakens the state. This is not so with communist historiography, which celebrates precisely class struggles and the weakening of the always-unjust social order and (in a more muted way) the weakening of the state. But when communist historiography turned to nationalism, it began extolling statehood, which then created a contradiction with the positive evaluation of class struggles (which a truly Marxist historiography cannot give up).

The master narrative of the Bulgarian Middle Ages is national in several respects. To begin with, the framework of the narrative is national - that is, it narrates almost exclusively what took place within the confines of the Bulgarian state, while what took place outside is narrated only cursorily and insofar as it relates to domestic developments. Secondly, the narrative takes a national perspective or point of view, from which the past is retrospectively configured and colored and, in the process, is "nationalized". It is conducted from the perspective of the collective "we" (with full identification), opposed to the others or "them", who appear most often in the role of enemies or even "hereditary enemies". In the Bulgarian case, the archenemy is the Rhomios or Romaioi (initially identified in national terms as "Greeks") of the Byzantine Empire. Enmity with the Rhomios was fed by the attitudes and the struggles against Greek influence during the Bulgarian National Revival (i.e. national formation) in the late Ottoman Empire and by the struggle over Macedonia subsequently. 
However, the problem is that most of what is known about the Bulgarians (their rulers, wars, and borders) comes from "others" that they have come in contact with. What is largely lacking is the domestic Bulgarian view on things, with its priorities, its group consciousness, and its own interpretation of the world (only small fragments of which can be recovered, through domestic, mostly "apocryphal" or "legendary" sources). To make things worse, most of the foreign sources are Byzantine ${ }^{32}$. In other words, they come from the Bulgarians' archenemies. This makes necessary to "reverse" the optic of the sources in order to extract an internal position from the external narration; in the process the observed is identified as "we" and even becomes an observer (of the Byzantine observer). When it is about wars, the enemy from the sources has to become "us", and the "we" from the sources has to become the enemy. The medieval Bulgarians, as "ours", then become the "good ones" and should always be in the right and their actions justified. This leads to strong criticism (and sometimes hyper-criticism) of the foreign sources: selective reading (which neglects or suppresses bad and reprehensible things about Bulgarians), finding the desired interpretation "between the lines", and other similar approaches. For example, when descriptions of Bulgarian atrocities appear in the sources (of the kings Simeon, Asen I, reign: 1190-1196, or Kaloyan-Ioannica, reign: 1197-1207), the national narrative's solution is either to ignore the uncomfortable aspects or to attempt to justify them as a well-deserved revenge on the Byzantines for a previous offense. Of course, critical reading of the sources is a major method of scientific historiography, but what I mean here is selective and self-serving hyper-criticism. This is criticism of the sources designed to discredit facts inconvenient to the national narrative, such as the question of participation of Vlachs in the uprising of Asen and Petăr in 1185-1187, which led to the establishment of the Second Bulgarian Kingdom, and to support those that are nationally advantageous.

In addition to framework and perspective, the master national narrative of the Bulgarian Middle Ages nationalizes and thus modernizes the past in a third, more substantive way. It presents the medieval Bulgarian states on the model of modern nation-states, where nation and territory coincide, even if the author denies it and does not speak of a nation but of ethnic community or nationality: narodnost. This is expressed (as already noted) by projecting onto the past the modern territorial national ideal of a Greater Bulgaria (as defined in the Treaty of San Stefano) consisting of Moesia, Thrace, and Macedonia and affirming an ideal and primordial "all-encompassing" Bulgaria. It is true that this "mental map" almost coincides with the periods of greatest Bulgarian expansion during the Middle Ages themselves. But the issue is that the "liberation" and "unification" of these lands is described as an ideal and a goal of the medieval rulers themselves. Hence the outermost parts

32 On sources, seе М. КАЙМАКАМОВА, Бблгарската средновековна историопис, София 1990, p. 7-65; В. Гюзелев, Средновековна България в светлината на нови извори, София 1981, p. 17-41. 
of this "mental Bulgaria" (or Bulgaria "in the mind" - the mind of the nationalists), which in fact usually lay outside the actual Bulgarian state, are named and treated as the "Bulgarian Northwest", "Bulgarian Northeast", and "Bulgarian Southwest" (though a "Bulgarian Southeast" is lacking perhaps because of the Byzantine predominance there). Furthermore, the Hungarians, Serbs, and even the Byzantines who ruled over them at various times are called invaders. Hence the Bulgarian rulers are also ranked in terms of "greatness" according to their success in expanding the borders to match the desired ones. Connected with that, most of the Balkan Slavs - not only those within the Bulgarian state's borders but also in other territories claimed by modern Bulgaria - are designated "Bulgarian Slavs", and the way they joined the state is depicted as "liberation" or "rescue" (from Byzantine assimilation). Interestingly, there is no place in the Bulgarian national narrative for "Byzantine Slavs", though many lived on Byzantine territory and were subjects of the Empire.

In a similar sense of nationalization of history is the projection of the modern national unity and homogeneity backwards onto the past. This refers to the idea of an ethnically and culturally unitary Bulgarian (Slavic) nationality, formed as early as the tenth century and preserved later on with roughly the same homogeneity, despite numerous ethnic admixtures. Also connected with this is the exaggeration of the ethnic or "national" consciousness and of its potency and efficiency in the Middle Ages. This is the case despite the fact that the socialist authors in particular negate the existence of nations at that time and speak of narodnost (a kind of pre-national ethnic community), yet endow it with the characteristics of a consolidated modern nation, including national consciousness and patriotism.

Some historians present medieval Bulgaria in a paradoxical way. They treat it simultaneously as a "nation-state", in the above meanings of ethnic homogeneity and ethnic boundaries coinciding with state boundaries (at least ideally), and a medieval "empire", which is by definition multiethnic and indifferent to ethnicity (and based on the imperial institutions and on a universal religion). The assertion of the imperial ideal comes mostly from the historian's identification with the dreams of Simeon the Great of conquering Constantinople and replacing the Byzantine Empire with a Bulgarian or Slavic-Byzantine Empire. Historians such as Ivan Bozhilov deploy their own variant of the master national narrative, which rotates around the imperial idea and looks at the course of history in this light ${ }^{33}$. As is well known, this did not happen, and Bulgaria remained (figuratively speaking) a "nation-state", ethnically heterogeneous though it was. Yet the paradox remains on a conceptual and logical level. What this demonstrates is that national/nationalist sentiments do not preclude pride in an even more glorious empire.

\footnotetext{
${ }^{33}$ И. Божилов, Цар Симеон Велики (893-927). Златният век на средновековна България, София 1983; IDEм, Седем етюда по средновековна история, София 1995, p. 94-129, 131-215.
} 
An attempt at a very different narrative of the Bulgarian Middle Ages was undertaken only by the crude Marxist (more accurately, Stalinist) historiography in the second half of the 1940s through the 1950s, in sharp opposition to the "bourgeois" (branded as "chauvinist") historiography ${ }^{34}$. What is meant here is the attempt of the communist regime to elaborate and impose its own, supposedly Marxist version of the Bulgarian medieval history, but very simplified according to contemporary Stalinist tenets, a kind of Marxist vulgata. This Stalinist counter-narrative had its own conceptual and theoretical schemes (preconceived and a priori), its own explanations (of driving forces and personal motivations), and its own logics and interpretative strategies, which were applied to the historical actors, events, institutions, phenomena, and developments or processes. At the center of this vision of history stands the teaching of the socioeconomic formations (in this case, feudalism), the teaching of basis and superstructure within each formation (which prioritizes the economy and social-class relations that emerge from it), and the teaching of class struggles as a driving force of social development and progress. The crude Marxist narrative emphasizes structures and processes rather than individuals and events.

This counter-narrative did not merely supply other interpretations and explanations of medieval historical figures, events, institutions, phenomena, and processes of the master national narrative. It also brought into focus and elaborated on its own topics and plots, especially feudalism as a socioeconomic formation, classes, and class struggles. Furthermore, it spotlighted heroes of its own, such as Pop (priest) Bogomil in the tenth century, the heretic; Ivaylo, the leader of a peasant uprising in 1277-1280; and Momchil, the adventurous fighter against the Turks in the first half of the fourteenth century. In a certain sense, the crude Marxist (Stalinist) narrative cannibalizes the master national narrative by replacing its plot lines and more general explanatory concepts and schemes (such as ethnic dualism, the Byzantine influence, personal qualities of the rulers, etc.) with its own - mostly feudalization processes and class relations. It also gives other causal explanations for some events and phenomena (especially with class motivations and struggles). Because it used preconceived schemes and ideas, this narrative interpreted the sources arbitrarily and departed drastically from the historical realities yet remained an interconnected narrative that made sense of things and possessed primarily rhetorical means of persuasion.

The Stalinist narrative on the Bulgarian Middle Ages also did not transcend the national framework of historical writing, and in this sense it was also a national (counter)-narrative. It was consistently implemented only for a short time in Bulgarian historiography and, even then, only in various blends with the national one.

\footnotetext{
${ }^{34}$ История на България, vol. I, София 1954. This is the textbook version of the Marxist national narrative of the Middle Ages.
} 
The communist regime itself, after consolidating power, turned toward nationalism and started encouraging the national narrative. This narrative had a much stronger potential for legitimation than sympathies with the anti-state and antiestablishment class struggles (which were useful for communists while in opposition but not while in power).

What goals are served by the master national narrative of the Bulgarian Middle Ages? They are the same served by master national narratives elsewhere. The most fundamental of these is the building of national identity by placing the national community within the framework of history: a story of origins, identification with a certain territory, and assertion of ethnic continuity from the forefathers to the present day. Connected with this, but more emotionally, is the fostering of national awareness and pride as well as a certain solidarity within the national community. In this respect (as Ernst Renan noted long ago), the narrative about sufferings and victimization (in the Bulgarian case, about the "Turkish yoke") works even stronger toward solidarity.

The master national narrative also has contemporary political objectives. It can suggest and inspire national political projects and goals, especially irredentist ones such as "unification" and "liberation", which in the Bulgarian case were especially relevant in the prewar and interwar period. The medieval past served to justify Bulgarian "historical rights" over certain territories as "originally Bulgarian" (especially Macedonia). But even if irredentism was not on the agenda, the master national narrative served to legitimize the ruling elites at a given time simply through historical continuity, in which they are supposedly the last link. They can even see themselves as fulfillers of "historical" objectives and ideals, creators of a new "golden age" (as Communist Party leaders saw themselves in late socialism). On the other hand, the historical narrative can also be implicitly critical of the rulers at a given moment, as not worthy of a glorious past and the "national legacies".

Authors of the master national narrative are historians in the role of "nationbuilders", in other words, creators of national identity and national pride through history - a typical role of nineteenth-century historians all over Europe ${ }^{35}$. The master national narrative of the Bulgarian Middle Ages was formed through the joint efforts of hundreds of historians, but during the "bourgeois era", Zlatarski and Mutafčiev were especially significant and comprehensive in their scope. Later historians usually made "contributions" to individual problems, though among them as well, a few stand out for the breadth of their work, such as Ivan Dujchev

${ }^{35}$ On Western Europe, see Writing National Histories... On Central Europe and the Balkans, see Historians as Nation-Builders... On the Greek case of writing national history, see E. GAZI, Scientific National History. The Greek Case in Comparative Perspective (1850-1920), Frankfurt am Main-New York 2000; EADEM, Theorizing and Practising 'Scientific' History in South-Eastern Europe (NineteenthTwentieth Century): Spyridon Lambros and Nicolae Jorga, [in:] Nationalizing the Past..., p. 192-208. 
(1907-1986) ${ }^{36}$, Dimităr Angelov (1917-1996) ${ }^{37}$, and a few from the following generations, especially the above-mentioned Ivan Božilov (1940-2016) and Vasil Gjuzelev (b. 1936) . $^{38}$.

The first "critical" Bulgarian historians (notably Spiridon Palauzov and Marin Drinov) lived in Russia and were mostly under Russian scholarly influence. The few medievalists from the independent "bourgeois" era specialized in Germany and were mostly under German scholarly influence. Under socialism, the influence of Russian and Soviet historiography predominated, while - notably - there was virtually no influence from the French Annales school, which was especially innovative with regard to the Middle Ages. On the whole, it seems that even now, mainstream Bulgarian historiography (despite some new tendencies) still considers its major task to be the defense and justification of the (Bulgarian) nation. And indeed, mainstream Bulgarian historiography has remained outside the new historiographical tendencies after World War II of writing history in other ways and for other purposes.

\section{Bibliography}

ANGelov D., Bogomilstvoto v Bălgarija, ${ }^{3}$ Sofija 1980.

ANGelov D., Obrazuvane na bălgarskata narodnost, Sofija 1971.

Berger S., Geschichten von der Nation. Einigen vergleichende Thesen zur deutschen, englischen, französischen und italienischen Nationalgeschichtsschreibung seit 1800, [in:] Die Nation schreiben. Geschichtswissenschaft im internationalen Vergleich, ed. C. Conrad, S. ConRaD, Göttingen 2002, p. 49-77.

Berger S., Introduction: Towards a Global History of National Historiographies, [in:] Writing the Nation. A Global Perspective, ed. S. Berger, Basingstoke 2007, p. 1-29, https://doi.org/10.1057/ 9780230223059_1

Berger S., The Power of National Pasts: Writing National History in Nineteenth- and Twentieth-Century Europe, [in:] Writing the Nation. A Global Perspective, ed. S. Berger, Basingstoke 2007, p. 30-62, https://doi.org/10.1057/9780230223059_2

Berger S., The Search for Normality. National Identity and Historical Consciousness in Germany since 1800, Providence-Oxford 1997.

\footnotetext{
${ }^{36}$ Dujchev authored one monograph (on Saint Ivan Rilski) and more than 500 scholarly articles on virtually every aspect (less on the economy) of Bulgarian medieval history.

${ }^{37} \mathrm{D}$. Angelov is known especially for his work on the Bulgarian ethnogenesis: Д. Ангелов, Образуване на българската народност, София 1971, and on the heretic sect of the Bogomils: IDEм, Богомилството в България, ${ }^{3}$ София 1980 as well as for numerous works on economic and social issues of the Bulgarian Middle Ages.

${ }^{38}$ Vasil Gjuzelev first became known for his book on the Bulgarian baptizer prince Boris I, which marked the turn to nationalism. See В. Гюзелев, Княз Борис I, София 1969. Hе also authored numerous specialized monographs and more popular books.
} 
Berger S., Donovan M., Passmore K., Apologias for the Nation-State in Western Europe since 1800, [in:] Writing National Histories. Western Europe since 1800, ed. S. Berger, M. Donovan, K. PAssmore, London-New York 1999, p. 3-14.

Božılov I., Car Simeon Veliki (893-927). Zlatnijat vek na srednovekovna Bălgarija, Sofija 1983.

Božılov I., Sedem etjuda po srednovekovna istorija, Sofija 1995.

Burguière A., L'historiographie des origines de la France: Genèse d'un imaginaire national, "Annales: histoire, sciences sociales" 58.1, 2003, p. 41-62, https://doi.org/10.1017/S0395264900002560

DASKalov R., Golemite razkazi za Bălgarskoto srednovekovie, Sofija 2018.

Djokić D., Whose Myth? Which Nation? The Serbian Kosovo Myth Revisited, [in:] Gebrauch und Missbrauch des Mittelalters, 19.-21. Jahrhundert, ed. J. BAK, J. JARnut, P. Monnet, B. SCHNEIDMÜLLER, Munich 2009, p. 215-233.

Effros B., The Germanic Invasions and the Academic Politics of National Identity in Late NineteenthCentury France, [in:] Gebrauch und Missbrauch des Mittelalters, 19.-21. Jahrhundert, ed. J. BAK, J. JARnut, P. Monnet, B. SCHNeIdmülLer, Munich 2009, p. 81-94.

Gazi E., Scientific National History. The Greek Case in Comparative Perspective (1850-1920), Frankfurt am Main-New York 2000.

Gazi E., Theorizing and Practising 'Scientific' History in South-Eastern Europe (Nineteenth-Twentieth Century): Spyridon Lambros and Nicolae Jorga, [in:] Nationalizing the Past. Historians as Nation Builders in Modern Europe, ed. S. Berger, C. Lorenz, Basingstoke-New York 2010, p. 192-208, https://doi.org/10.1057/9780230292505_10

Geary P., "Multiple Middle Ages" - konkurrierende Meistererzählungen und der Wettstreit um die Deutung der Vergangenheit, [in:] Meistererzählungen vom Mittelalter, ed. F. Reхrotн, Munich 2007, p. 107-120, https://doi.org/10.1515/9783110651119-008

Geary P., The Myth of Nations. The Medieval Origins of Europe, Princeton-Oxford 2002.

GJuZelev V., Knjaz Boris I, Sofija 1969.

Gjuzelev V., Srednovekovna Bălgarija v svetlinata na novi izvori, Sofija 1981.

Historians as Nation-Builders. Central and South-East Europe, ed. D. Deletant, H. HAnAK, Basingstoke-London 1988.

Hunt L., Geschichte jenseits der Gesellschaftstheorie, [in:] Geschichte schreiben in der Postmoderne, ed. C. Conrad, M. Kessel, Stuttgart 1994, p. 98-122.

Istorija na Bălgarija, vol. I, Sofija 1954.

Jarausch K., Die Krise der nationalen Meistererzählungen, [in:] Die historische Meistererzählung. Deutungslinien der deutschen Nationalgeschichte nach 1945, ed. K. JaRAusCH, M. SABRow, Göttingen 2002, p. $140-162$.

Jarausch K., Sabrow M., "Meistererzählungen": Zur Karriere eines Begriffs, [in:] Die historische Meistererzählung. Deutungslinien der deutschen Nationalgeschichte nach 1945, ed. K. JARAUsch, M. SABRow, Göttingen 2002, p. 9-35.

Kајмакамоva M., Bălgarskata srednovekovna istoriopis, Sofija 1990.

Kreiswirth M., Tell Me a Story: The Narrativist Turn in the Human Sciences, [in:] Constructive Criticism. The Human Sciences in the Age of Theory, Toronto-Buffalo-London 1995, p. 61-87.

Lambert P., The Professionalization and Institutionalization of History, [in:] Writing History. Theory and Practice, ed. S. Berger, H. Feldner, K. Passmore, London 2003, p. 42-60. 
Leerssen J., Setting the Scene for National History, [in:] Nationalizing the Past. Historians as Nation Builders in Modern Europe, ed. S. Berger, C. Lorenz, Basingstoke-New York 2010, p. 71-85, https://doi.org/10.1057/9780230292505_4

Lyotard J.-F., The Postmodern Condition. A Report on Knowledge, Manchester 1984.

Megill A., "Grand Narrative" and the Discipline of History, [in:] A New Philosophy of History, ed. F. Ankersmit, H. Kellner, Chicago 1995, p. 151-173.

Middell M., Gibas M., Hadler F., Sinnstiftung durch historisches Erzählen. Überlegungen zu Funktionsmechanismen von Representationen des Vergangenen, [in:] Comparativ, Zugänge zu historischen Meistererzählungen, ed. M. Middell, M. Gibas, F. HAdler, Leipzig 2000, p. 7-35.

MutAFČIEv P., Istorija na bălgarskija narod, vol. I-II, Sofija 1943.

MutAFČIEv P., Iztok i Zapad v evropejskoto srednovekoje, Sofija 1999.

MutafČIev P., Kniga za bălgarite, Sofija 1999.

Nikov P., Bălgari i tatari prez Srednite vekove, Sofija 1929.

Niкov P., Bălgaro-ungarski otnošenija ot 1257 do 1277 godina, “Сборник на Българската академия на науките" / "Sbornik na Bălgarskata akademija na naukite" 11, 1920, p. 1-220.

Niкov P., Sădbata na severozapadnite bălgarski zemi prez Srednite vekove, “Българска историческа библиотека" / "Bălgarska istoričeska biblioteka” 3.1, 1930, p. 96-153.

Nikov P., Tataro-bălgarski otnošenija prez Srednite vekove s ogled kăm caruvaneto na Smileca, Sofija 1921.

Oexle O., "Das Mittelalter": Bilder gedeuteter Geschichte, [in:] Gebrauch und Missbrauch des Mittelalters, 19.-21. Jahrhundert, ed. J. BaK, J. Jarnut, P. Monnet, B. Schneidmüller, Munich 2009, p. 21-43.

PoHL W., Modern Uses of Early Medieval Ethnic Origins, [in:] Gebrauch und Missbrauch des Mittelalters, 19.-21. Jahrhundert, ed. J. BAK, J. Jarnut, P. Monnet, B. SChneidmüller, Munich 2009, p. 55-70.

Poнl W., Ursprungserzählungen und Gegenbilder. Das archaische Frühmittelalter, [in:] Meistererzählungen vom Mittelalter, ed. F. Rехroth, Munich 2007, p. 23-41, https://doi.org/10.1515/ 9783110651119-003

Raedts P., The Once and Future Reich: German Medieval History between Retrospection and Resentment, [in:] Gebrauch und Missbrauch des Mittelalters, 19.-21. Jahrhundert, ed. J. BAK, J. JARnUt, P. Monnet, B. SCHNEIDMÜLler, Munich 2009, p. 193-204.

Rexroth F., Meistererzählungen und die Praxis der Geschichtsschreibung. Eine Skizze zur Einführung, [in:] Meistererzählungen vom Mittelalter, ed. F. Rexroth, Munich 2007, p. 1-22, https:// doi.org/10.1515/9783110651119-002

RüSEN J., Für eine interkulturelle Kommunikation in der Geschichte, [in:] Die Vielfalt der Kulturen (Erinnerung, Geschichte, Identität 4), ed. J. Rüsen, M. Gottlob, A. Mittag, Frankfurt am Main 1998, p. 12-36.

Šuica M., The Image of the Battle of Kosovo (1389) Today: A Historic Event, a Moral Pattern, or the Tool of Political Manipulation, [in:] The Uses of the Middle Ages in Modern European States, ed. R.J.W. Evans, G.P. Marchal, Basingstoke 2011, p. 152-174, https://doi.org/10.1057/ 9780230283107_10

Welsкopp T., Identität ex negativo, [in:] Die historische Meistererzählung. Deutungslinien der deutschen Nationalgeschichte nach 1945, ed. K. Jarausch, M. SABrow, Göttingen 2002, p. 109-139. 
Writing National Histories. Western Europe since 1800, ed. S. Berger, M. Donovan, K. Passmore, London-New York 1999.

ZlatARski V., Istorija na bălgarskata dăržava prez srednite vekove, vol. I, Părvo bălgarsko carstvo, p. 1, (Epoha na hunno-bălgarskoto nadmoštie, 679-852), Sofija 1918.

ZlataRski V., Istorija na bălgarskata dăržava prez srednite vekove, vol. I, Părvo bălgarsko carstvo, p. 2, (Ot slavjanizacijata na dăržavata do padaneto na Părvoto bălgarsko carstvo, 852-1018), Sofija 1927.

ZLATARSKI V., Istorija na bălgarskata dăržava prez srednite vekove, vol. II, (Bălgarija pod vizantijsko vladičestvo, 1018-1187), Sofija 1940.

ZLATARSKI V., Istorija na bălgarskata dăržava prez srednite vekove, vol. III, (Vtoro bălgarsko carstvo. Bălgarija pri Asenovci, 1187-1280), Sofija 1940.

\begin{abstract}
The article is a brief and schematic presentation of the notion of a "master narrative" and of the master narrative of the Bulgarian Middle Ages, which is the subject a detailed book of mine in Bulgarian. This master narrative was constructed starting with what is known as "Romantic" historiography (from Monk Paisij”s "Istorija Slavjanobolgarskaja” [Slavonic-Bulgarian History] in 1762 to Vasil Aprilov's writings in the first half of the nineteenth century) but it was elaborated especially with the development of "scientific" (or critical) historiography first by Marin Drinov (1838-1906) and mainly by the most significant Bulgarian historians from the "bourgeois" era: Vasil Zlatarski (1866-1935), Petăr Mutafčiev (1883-1943), and Petăr Nikov (1884-1938). Then it was interrupted by the (crude) Marxist counter-narrative of the late 1940s through the 1960s. Starting in the late 1960s there was a gradual return to the nationalism of the master national narrative, which reached a peak with the celebration of the $1,300^{\text {th }}$ anniversary of the founding of the Bulgarian state in 1981 . The same line continued after 1989 (stripped of the Marxist vulgata), yet some new tendencies appeared.
\end{abstract}

Keywords: master narrative, grand narrative, metanarrative, counter-narrative, Bulgarian Middle Ages, King Samuil, Khan Asparuh, Khan Kubrat, Tsar Simeon the Great, Tsar Ioan Asen II, San Stefano Treaty, Ivaylo's peasant uprising, Bogomil heresy, Tsar Asen I

Roumen Daskalov

New Bulgarian University 21 Montevideo str. 1618 Sofia, Bulgaria roumen.daskalov@gmail.com 